\title{
Issues in Financial Institution Capital in Emerging Market Economies
}

\author{
Allen B. Frankel
}

\section{INTRODUCTORY REMARKS}

For the past twenty years, Asia has been regarded as an economic success story. The recent economic turmoil in the region, however, has prompted a reevaluation of the longterm sustainability of the dynamic economic performance. Undoubtedly, lessons will be drawn from the Asian experience-lessons that will inform future decisions at various levels to move financial liberalization forward while providing for prudential concerns.

Many thoughtful analysts surveying the Asian experience have focused on the inadequacies and inefficiencies in the banking systems of Asian nations as particularly significant elements in precipitating the current crisis. The banking problems of these nations, however, only bring into specific relief deep, complex, and more pervasive problems in the institutional arrangements of the affected nations-problems that are, in fact, common to many emerging market countries throughout the world. These issues have particular relevance to the consideration of future financial liberalization and the broadening of the international financial community via multilateral trade negotiations and international understandings among national financial supervisors.

Allen B. Frankel is the chief of the International Banking Section of the Division of International Finance at the Board of Governors of the Federal Reserve System.

\section{An Outline of the Policy Problem}

This paper sets out to discuss a policy problem involving the integration of emerging market banking systems into international financial markets. Below is an outline of the policy problem:

Policy problem. Promote financial market liberalization in emerging economies through the exploitation of international financial linkages, including interbank transactions.

Constraint. Satisfy system-wide prudential policy needs.

Premise. As long as entry of foreign banks is restricted, domestic banks have superior capacity to gather information on domestic economic actors and discriminate among those actors.

Instruments that can be applied to the solution of the policy problem:

- robust institutional arrangements; ${ }^{1}$

- design of macroeconomic policy instruments;

- binding international agreements such as the Financial Services Agreement of the General Agreement on Trade and Services; and

- multilateral understandings such as the Basle Core Principles. 
This paper is organized as follows. In Section III, we explicate the policy problem through an overview discussion of the Asian experience. In Section IV, we consider institutional deficiencies in emerging market countries and their negative implications for prudent banking. We also extend the discussion to include the impact of institutional issues on the credit relationships between domestic and foreign banks. In Section V, we discuss the relevance of trade agreements in financial services and agreements among supervisors to the process of integrating emerging markets into international banking markets. Drawing on the insights of incomplete contracting theory, we consider how the involvement of emerging market countries might influence both the form and the coverage of multilateral agreements covering prudential standards.

\section{Putting The Policy Problem IN CONTEXT}

Our statement of the general policy problem has been informed by the Asian experience. Many observers link the poor macroeconomic performance of Asian emerging market countries in the recent past to an inconsistency in economic policy: although these countries encouraged domestic institutions to be actively involved in international financial markets, they did not at the same time aggressively pursue domestic institutional reform. The Asian economies made efforts to implement financial market liberalization by removing restrictions, for example, on the character and magnitude of funding activities that Asian banks could conduct in international interbank markets.

Over the last decade, Asian governments sought to support the preeminent role of their banking systems as sources of finance for investment projects by removing interest rate controls and by initiating other liberalizing measures designed to avoid disintermediation. The policies were successful in that they permitted seemingly wellcapitalized banks to assume investment responsibility for large amounts of domestic and foreign savings. They were unsuccessful, ex post, in that many of the projects financed did not generate sufficient revenues to meet contractual loan payments. The eventual result has been the current crisis in Asia, which has generated both domestic economic problems in affected Asian countries and concern about the impact on banks in other countries. This outcome can be associated with the deficient state of institutional arrangements in emerging Asian economies. In particular, these economies commonly lack complete legal arrangements as well as well-developed mechanisms to produce good accounting information. In turn, this produces a lack of transparency in corporate financial affairs, distorted incentive structures for economic agents, and a lack of certainty as to the locus of corporate control. In the next section, we will look more closely at how the deficient institutional arrangements create difficulties for the making of prudent credit decisions and can in fact generate prudential concerns.

\section{INSTITUTIONAL FAILINGS:} ASIAN EXAMPLES

\section{A. Accounting, Monitoring, AND MACROECONOMIC POLICY}

As noted above, many emerging market countries lack strong accounting mechanisms and traditions. Numerous factors may contribute to these weaknesses. First, many countries lack legal requirements for the independent auditing of financial statements. Second, the limited penetration of sophisticated accounting systems in many emerging market countries reduces the quality and timeliness of financial data. In addition, the lack of liquid, well-developed asset markets in these nations often limits the validity of financial information; companies must use internal estimates of values rather than objective, transparent, market-based observations. Finally, the values of corporate transparency, avoidance of conflicts of interest, and safeguarding of corporate assets are not fully ingrained in some of the emerging markets.

Furthermore, macroeconomic policies in emerging markets often make prudent banking more difficult, as foreseeable consequences of those policies cannot be managed readily by emerging market banks with underdeveloped risk management systems. As the Asian experience demonstrates, the choice of exchange rate regime can introduce instability into the domestic banking markets. To some extent, this occurred in Mexico in 1994 and 1995. The most striking example of this phenomenon, however, took place in Chile in the late 1970s. Diaz-Alejandro 
(1983) reported that real lending rates in Chile averaged more than 75 percent per annum over the period 1975-82. It was not surprising to him that, in these circumstances, Chilean banks borrowed heavily in foreign currency and lent the proceeds to domestic customers. Finally, he noted that Chilean banks had not taken into account the substitution of exchange rate risk exposure for credit risk. This failure, in turn, contributed to Chilean bank failures.

\section{Stylized Example}

To provide additional insight into the impact of these institutional issues on banking markets, we will present a stylized example based on the Asian experience. To begin with, let us consider the economic and financial circumstances present in Asia.

The slowdown in economic growth in Asia has been reflected in sharp deteriorations in the cash holdings (liquidity) of Asian companies. ${ }^{2}$ It seems apparent, based on available data, that in some cases companies chose to respond to these cash squeezes by taking on currency risk through arrangement and drawdowns of hard currency credit facilities from domestic and foreign banks. Companies found these hard currency credit facilities attractive because they permitted the companies to reduce the rate of drawdown of their cash reserves by lowering interest payments. The reduced cash flow came at the cost of the assumption of financial risk of a depreciation of the domestic currency.

The chart shows data for two countries: Korea and Thailand. For both of these countries, there was a strong association of the buildup of the foreign borrowing of domestic banks with the increase in domestic credit extensions to the domestic private sector. The greater steepness of the foreign bank borrowing line in both cases is consistent with a story that external bank borrowing was undertaken to accommodate the corporate sector's heightened interest in conserving scarce cash liquidity. We would caution, however, that available data do not permit us to verify the presumed behavior that banks passed on the currency risk to liquidity-constrained corporate borrowers.

Now let us develop our stylized example. Consider the following circumstances regarding the exchange rate environment. The monetary authorities are seeking to avoid currency depreciation through open-market purchases. To hold a position in the domestic currency, market participants require compensation in the form of higher domestic interest rates for the anticipated future depreciation. $^{3}$

Let us assume that the borrowing behavior described above is sufficiently prevalent among the borrowers of a particular bank that a depreciation of the exchange rate would significantly increase the credit exposures of that bank. Furthermore, assume that the bank's credit decisions are based on a single criterion, the borrower's credit history, reflecting the only information available to the bank. ${ }^{4}$ This assumption is based on the notion that domestic corporates either do not prepare financial data or that the data they prepare are of highly uncertain value and therefore cannot be relied on as a basis for credit decisions. An important characteristic of the data on the borrowing history is that they have only been accumulated during an observation period in which the sensitivities of borrowers' financial situations to exchange rate movements could not be observed.

Funding OF DOMESTIC BANK CREDIT IN INTERNATIONAL INTERBANK MARKETS

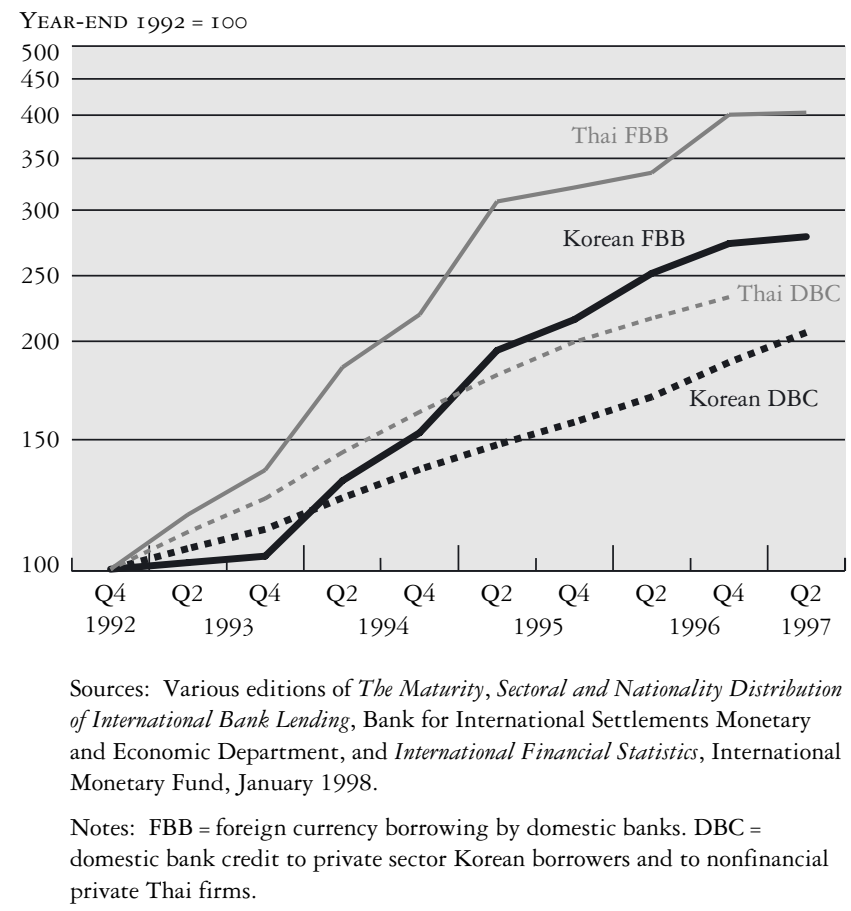


Now, let us consider the consequences to the bank of a depreciation of the currency. The immediate impact of the depreciation would be to increase exposures to all borrowers who have been loaned funds in the foreign currency. The bank, given the information available, would have no way to assess the consequences of the depreciation on the ability of any particular borrower to pay. The depreciation may have impaired the ability of some borrowers, who are unhedged, to honor their debt obligations. Other borrowers, however, who are effectively hedged (for example, those who have receivables denominated in the foreign currency) would not be adversely affected by the depreciation. Let us assume that a borrower of each type approaches the bank to restructure its loan. Each borrower requests that its loan payment, expressed in domestic currency, be no more than required before depreciation. Given the absence of firm financial information, the bank has no objective basis to differentiate among the two applicants for debt relief. Thus, the bank faces the possible result that if it gives concessional terms to both applicants, it has advantaged one unnecessarily. If it does not permit the concessional terms, it forces one borrower into bankruptcy unnecessarily. And if it takes the final choice and offers one concession and denies the other, it faces the possibility of ending up in the worst of possible worlds in which one borrower defaults and the other is unnecessarily provided with reduced payments.

Now let us bring the domestic bank/foreign bank relationship into our analysis. Assume that the only information disclosed to a foreign bank is data on the level of nonperforming loans of the domestic bank. In the period before depreciation, differences in the levels of nonperforming loans among banks would not have systematically revealed the hedging or nonhedging of these banks' borrowers. The analysis above suggests that if the concentration of a bank's loans is to unhedged borrowers, then depreciation might result in a large increase in nonperforming loans. But this characteristic of the bank's loan portfolio would be revealed only ex post. This demonstrates how the foreign bank, in the absence of effective monitoring mechanisms, would not have the wherewithal to alter the way it processes information and makes credit decisions. Such mechanisms could inform decision making at foreign banks, and could therefore lead to avoidance of exposures to those domestic banks likely to be affected by a currency depreciation.

This example suggests the potential value of forward-looking information. Such information can be produced by stress tests. ${ }^{5}$ The tests are particularly useful when historical experience has been limited by successful government efforts to fix asset prices (most prominently, fixed exchange or interest rates). The information drawn from these tests can support alternate projections of cash flows, so bank managements can take various contingencies into account for purposes of capital planning. ${ }^{6}$

\section{B. THE BANKRUPTCY REgIME}

Let us now turn to the relevance of a country's bankruptcy regime on the relationship between the domestic bank and the domestic borrower as well as between the foreign bank and the domestic bank. We will consider how deficient rules for corporate debt workouts, and in particular violation of the absolute priority rule (APR), undermine the ability of both domestic banks to make credit decisions on the corporate level and foreign banks to make discriminations among domestic banks in the interbank market. Again, the experience of Asia is both especially instructive and particularly relevant.

Economic analysis of bankruptcy arrangements has focused on the impact of the bankruptcy regime, and in particular the absolute priority rule, on the efficiency of financial contracting (see Longhofer [1997]). The absolute priority rule provides for the retention in bankruptcy of the priority of claims established outside of bankruptcy. In other words, the most senior creditors should be paid off before anything is given to the next senior creditors, and so on down to the shareholders.

Asian countries appear to have a high tolerance for violations of APR. This has been traced by legal scholars to Asian cultural traditions as well as to the influence of European civil law heritages in a number of countries, including Indonesia. ${ }^{7}$ The character of significant violations of APR, which we think are prevalent, is suggested by the following examples. In a recent restructuring of a major Thai 
company with $\$ 330$ million in debt, creditors will forgive 95 percent of their debt and shareholders will retain an interest in the company. The terms reflect the power of the dominant shareholder to veto proposed restructuring arrangements, a widely recognized shortcoming of Thailand's bankruptcy arrangements. ${ }^{8}$

In the case of Korea, violations of APR have been associated with the behavior of entrenched managements. The managements of bankrupt chaebols and other large Korean companies have been able to apply for court mediation which, when granted, has permitted them to stay in place. This process violates the absolute priority rule because control of corporate assets has not been transferred to the new owners. The Korean government has now proposed legislation that restricts the opportunities of managements at troubled companies to entrench themselves. ${ }^{9}$

Now let us evaluate the impact of violation of APR on the creditor relationship between the domestic bank and borrower. The higher the probability of APR violations in a given legal structure, the less incentive owners/ managers have to avoid bankruptcy. The lessened incentive reflects the diminished discrepancy in outcomes between the bankruptcy and nonbankruptcy states. In these circumstances, the domestic creditor bank would be less favorably treated than in the absence of APR violations.

Consider the case where the domestic bank does have special ability vis-à-vis foreign banks to discriminate between domestic companies as to the likelihood of default. The presence of such a superior capacity helps explain why foreign banks would choose to fund domestic banks' extensions of credit to domestic borrowers. That is, the presence of APR violations enhances the domestic banks' advantage.

To summarize, badly structured bankruptcy regimes can result in the increased likelihood of bankruptcy (because of the reduction in incentives) and reduced recoveries in states of bankruptcy, and thus will tend to reduce the attractiveness for creditors of debt positions in those economies. As well, poor bankruptcy arrangements increase the likelihood that foreign banks will use domestic banks as intermediaries in lending relationships with domestic corporate borrowers.
Our analysis above provides a basis for the presumption that the interests of emerging market countries would be served by addressing institutional failings. Additionally, instability in domestic financial markets associated with such institutional arrangements could be transmitted to international markets. Therefore, international supervisors also have incentives for evaluating the state of institutional arrangements in emerging market countries when considering whether and how to negotiate on international prudential and financial liberalization issues.

\section{Multilateral Agreements}

This section reviews the consequences of the size and composition of the group participating in international prudential and liberalization agreements on the contractual character of those agreements. In particular, we focus on the significance for international liberalization and supervisory arrangements on the inclusion of emerging market countries. In connection with this discussion, we review three agreements: the Basle Capital Accord, the Financial Services Agreement of the General Agreement on Trade and Services, and the Basle Committee's Core Principles for Effective Banking Supervision.

\section{A. Basle CAPital ACCORD}

The Basle Capital Accord is an understanding among the bank supervisory agencies of the G-10 member countries. The agreement, signed in 1988, was undertaken during a period when these authorities expressed interest in a shared-rule framework for judging the financial strength of applicant banks, which were, at that time, primarily from each other's countries. The thrust of the revised Basle Accord (updated to include the coverage by capital regulation of market risks) can be summarized as follows:

1. A bank must hold equity capital equal to at least a fixed percent of its risk-weighted credit exposures as well as capital to cover market risks in the bank's trading account.

2. When performance causes capital to fall below this minimum requirement, shareholders can retain control provided that they recapitalize the bank to meet the minimum capital ratio. 
3. If the shareholders fail to do so, the bank's regulatory agency is required to sell or liquidate the bank.

The Basle Accord provides de facto liberalization by establishing a transparent standard for the crucial variable, capital, that is used in making judgments on various applications, including those for entry, of foreign banks. Due to its transparent framework and simplicity, the agreement operates to limit discretion for supervisors in signatory countries and other countries that voluntarily chose to adhere to it.

It is instructive to consider what lessons the Accord provides regarding the factors that influence the outcome of contracting among groups of national supervisory authorities. Economic analysis of contracting would suggest that the small size and homogenous character of the group of signatories explain the simplicity of the Basle Capital Accord. These characteristics allowed the negotiations to be effectively limited to questions involving capital issues. ${ }^{10}$ Additionally, the cost and complexity of negotiations were reduced as the agreement does not involve formal treaty obligations and accords flexibility in national implementation.

Let us consider the case that can be made to use the Basle Accord as a complete and controlling international prudential agreement covering all banking systems, including those of the emerging markets. Four characteristics of the Basle Accord are inconsistent with this case.

First, the framers of the Accord implicitly presumed that the signatory countries had compatible institutional arrangements. As discussed above, in many cases the institutional failings of emerging market countries make them incompatible with those of established financial centers.

Second, the Accord is an incomplete agreement that affords considerable discretion to national supervisory authorities. For example, it provides no guidance as to how signatory supervisors should address failures of bank shareholders to meet agreed minimum requirements. The disparate implementation of prompt corrective action initiatives in the United States and Japan affirms this observation. ${ }^{11}$ Additionally, the Accord offers no specific guidance as to the circumstances in which a host country supervisor may close a branch office of a foreign bank. ${ }^{12}$ Because of the incomplete nature of the contract, national supervisors in G-10 countries have had to expend considerable effort to make adaptations and to develop informal understandings in order to keep the Basle Accord relevant and useful. Enlargement of the group of nations consulted in this process would considerably increase the costs of reaching consensus on modifications of the Accord and could possibly discourage needed adaptations.

Third, the Basle Accord is tightly focused on issues related to capital measurement and the setting of minimum capital adequacy standards. For example, it does not offer standards for banks' efforts to identify, measure, monitor, and control material risks. It would be important to reach agreement on standards such as these if the group of countries negotiating standards became more diverse.

Fourth, there is no formal enforcement mechanism in the Accord. In the signatory countries, there has been an increased understanding that formal enforcement mechanisms such as prompt corrective action are required at the national level. The same view, however, has not become as widely accepted in emerging market countries. In the absence of an enforcement mechanism, enlargement of the signatory group risks the introduction of a rogue national banking system into international markets. The presence of such a rogue signatory could undercut the understandings on which the normal functioning of the international interbank markets are based.

\section{B. The General Agreement on Trade And SER VICES AND THE BASLE CORE PRINCIPLES}

In this section, we will consider how emerging markets might be brought into the Basle-based discussions. To begin, however, it is important to appreciate the importance of the separate process of negotiating international liberalization organized under the aegis of the World Trade Organization.

The General Agreement on Trade and Services (GATS) promotes competitive and efficient markets worldwide. In particular, the Financial Services Agreement of GATS brought trade in financial services into a global multilateral framework comparable to that provided for 
trade in goods (see Key [1997]). The agreement calls for a process of liberalization involving the reduction or removal of barriers to foreign financial services and foreign financial services providers from national markets.

The coverage of financial services by GATS is modified by the so-called prudential carve-out. The carveout permits signatory countries to take measures for prudential purposes notwithstanding other GATS provisions. However, limited guidance has been provided as to what constitutes prudential measures. It is clear only that the carve-out permits measures for the protection of various classes of stakeholders such as policyholders and depositors or "to ensure the integrity and stability of the financial system." Therefore, fleshing out the meaning of the prudential carve-out requires reference to alternative sources.

Consider the character of guidance that would be provided for this concept by the recently drafted Basle Core Principles for Effective Banking Supervision. The Core Principles are intended to serve as a basic reference for supervisory and other public authorities. That is, they provide general, not detailed, guidance on an extensive listing of topics (see Basle Committee on Banking Supervision [1997]). The Core Principles were drafted by representatives from the Basle Committee's G-10 member countries and nine emerging market countries. Supervisors from all countries, however, are being encouraged to endorse the Core Principles. The Basle Core Principles comprise twenty-five basic standards that relate to: preconditions for effective banking supervision (Principle 1), licensing and structure (Principles 2 to 5), prudential regulation and requirements (Principles 6 to 15), methods of ongoing banking supervision (Principles 16 to 20), information requirements (Principle 21), formal powers of supervisors (Principle 22), and cross-border banking (Principles 23 to 25).

The Core Principles employ the concept of capital regulation established in the Basle Accord. To this they add an extensive set of supervision issues. One might interpret the greater breadth of the Principles as reflecting the now-established international sentiment that improvements need to be made in the supervisory systems of many countries.

\section{Vi. Alternatives to the Basle Accord Methodology}

The breadth of the Core Principles may make them more useful than the Basle Accord for extended application to the emerging market countries. As noted, however, the Core Principles still make use of the Basle Capital Accord. Therefore, some of the same arguments against the further expansion of Basle Accord signatory countries apply to the Core Principles as well. There is rather broad agreement that the Accord's methodology has flaws, but certainly no consensus on what, if any, alternative could or should replace it. In this section, we will make some observations regarding two of these alternative prudential methodologies. We will first consider fair pricing of deposit insurance and then the so-called precommitment approach.

\section{A. FAIR PRICING OF DEPOSIT INSURANCE}

John, Saunders, and Senbet (1995) have argued that countries should adopt fairly priced deposit insurance to avoid the distorting consequences for resource allocation associated with capital regulation. They argue that appropriate risk-adjusted deposit insurance premiums would provide bank owners with incentives to put in place optimal management compensation structures. The motivation for such a scheme would be to induce managers to avoid taking risks beyond those that are optimal for an "allequity-financed bank."

The experience in the United States indicates that implementation of risk-adjusted premiums is a politically difficult task. The range of risk-adjusted premiums now charged by the Federal Deposit Insurance Corporation is about 30 basis points, well below the approximately 100-basis-point range routinely estimated by researchers in the early 1990s as required to adequately account for risk differences among banks. The European experience also suggests that gaining agreement among countries on adopting risk-adjusted premiums would not be an easy task. In 1993, the European Commission issued the Directive on Deposit Guarantees requiring EU member nations to adopt a national system of deposit insurance that met broadly agreed-upon standards. ${ }^{13}$ National authorities were given wide latitude, however, in implementing the 
Directive in their home countries. Countries chose a wide variety of implementation mechanisms; only two, however, chose risk-adjusted premiums. ${ }^{14}$

\section{B. The PReCOMmitMent ApPROACH}

Now let us consider the possibility of substituting a precommitment-type approach for the current Basle Accord methodology. Under the precommitment approach, a bank commits to its regulator that it will not exceed a certain magnitude of loss for a period to come. Each bank determines this amount on its own. If the bank violates this commitment, then it faces a penalty, which must be viewed as credible in order for the approach to be effective.

To date, there has been little, if any, discussion regarding the challenges involved in ex post verification of periodic profit-loss outcomes. The reason for this dearth of deliberation seems clear-the precommitment approach raises no new issues in economies with strong accounting traditions and systems. However, if consideration were to be given to emerging market banks employing such an approach, verification would become an issue due to institutional shortcomings in these countries. In particular, recent discussions on the current operation of emerging market banking systems suggest that these systems are often characterized by a lack of transparency, a scarcity of supervisory personnel with requisite technical training, incomplete avoidance of conflicts of interest, and lax safeguarding of corporate assets by system participants. These deficiencies could undermine the verification procedure, which is a key aspect of a selfassessed regulatory approach. This discussion suggests that, at present, there are significant barriers to the use of incentive-compatible regulatory schemes in emerging market economies.

\section{ENFORCEMENT MECHANISMS}

So far, we have considered various international agreements and frameworks for dealing with prudential concerns and their relevance to a world in which a growing and increasingly diverse group of countries participate in international markets. As our final topic, we will discuss the arguments related to the choice of whether to include enforcement mechanisms in multilateral agreements on capital adequacy and associated prudential issues.

The argument for rewards and penalties is to provide incentives to participant countries to take actions that would tend to improve prospects for stability of the international financial system. Two obstacles, however, must be overcome. First, it would be difficult to ensure that enforcement actions are applied fairly and to insulate them from forces other than those related to prudential concerns. Second, supervisors would more closely scrutinize any proposals if the proposals were connected to a binding agreement. This would increase the difficulty of negotiating an agreement.

\section{CONCLUDING REMARKS}

A lesson of the Asian financial crisis concerns the macroeconomic costs of poorly designed institutional structures. One of the possible explanations for the persistence of the tolerance of these structures may be that they afford a competitive advantage to domestic financial institutions of emerging market countries. The competitive advantage of these banks is based on their value as intermediaries between international markets and domestic agents. This value arises from their knowledge of the intricacies of the institutional structures in their home countries.

Much of our discussion of the policy problem assumes that, going forward, emerging market supervisors will be included in the negotiation of multilateral supervisory understandings. The analysis of the paper suggests that their participation will influence the outcome of the nature of understandings among regulators. In particular, the outcome would likely result in an attainable standard that is consistent with a process of institutional reform over time. During this period of reform, emerging market banks would be insulated from the full consequences of market discipline and thus would retain some protection of their competitive status. This would result in an agreedupon strategy for integrating emerging market banking systems into international markets.

When relaxing the assumption that emerging market supervisors must agree to an international supervisory standard, the standard would move toward one 
that permits the most efficient employers of bank capital to fully exploit their competitive advantages. In the absence of protected franchises, few emerging market banks would be able to compete in the market for equity capital at this time. Under these conditions, one possible response of emerging market authorities could be to close off their markets to avoid direct competition between more efficient foreign banks and their less efficient domestic institutions. This could well be accompanied by lessened emphasis on institutional reform efforts. The costs of these policy measures would presumably be less real economic integration of emerging market economies with the international economy. We also cannot discount the possibility that the less complete and more slowly implemented institutional reforms will have a negative impact on systemic risk. This might occur if market participants failed to take into account in their own risk management actions a scaling back of the market-oriented oversight of banking and other financial supervisors in emerging market economies. 


\section{ENDNOTES}

The author wishes to acknowledge the extraordinary assistance provided by Garrett Ulosevich in the preparation of this paper. This paper presents the views of the author and should not be interpreted as reflecting the views of the Board of Governors of the Federal Reserve System or other members of its staff.

1. See Annex of Financial Stability in Emerging Market Economies, Report of the Working Party on Financial Stability in Emerging Market Economies. This report is available on the World Wide Web at the Bank for International Settlements' site (http://www.bis.org). It provides an illustrative List of Indicators of Robust Financial Systems. The six main headings of the listing are: 1) legal and juridical framework; 2) accounting, disclosure, and transparency; 3) stakeholder oversight and institutional governance; 4) market structure; 5) supervisory/regulatory authority; and 6) design of the safety net.

2. Korean data for deposits at banks by individuals and corporations show much stronger increases in growth of deposits of individuals in 1996 and 1997. In addition, Korean data show sizeable increases in foreign-currency-denominated bank loans equal to 47 percent between the end of 1995 and the end of the third quarter of 1997. That is, the Korean data appear to be broadly consistent with the circumstances described in the stylized example (Bank of Korea 1997).

3. See Krugman (1996) for a discussion of conventional currency crisis theory. See Krugman (1998) for an exposition of a model that concentrated on the problem of moral hazard in the financial sector and its macroeconomic consequences.

4. In the discussion of the stylized example, we abstract from the possible use of collateral. The credit policies in many emerging market economies are asset based rather than cash-flow based. Because banks do not require information on cash flows of the underlying asset, they are unable to evaluate independently the asset's value through discounted cash flow or similar methodologies. In such circumstances, collateral should provide the lender less comfort than when the collateral-assumed values are consistent with estimates derived from a discounted cash-flow analysis.

5. See Gibson (1997) for a discussion of how the design of an information system depends on the risk measurement methodology that a bank chooses.

6. For a discussion of the usefulness of cash-flow analysis in emerging market countries, see Kane (1995).

7. For overview discussions of the administration of insolvency laws across Asia, see Tomasie and Little (1997). Tomasie and Little have commented on the impact of Confucian philosophy on the resolution of financially troubled companies in Asia. They suggest that the cultural ideal of communal risk bearing results in an unwillingness to visit total loss on any class of stakeholders. Tomasie and Little have also commented on the separate influence of the European civil law tradition. They have observed that under this tradition, judges look first to the satisfaction of public policy objectives and only then consider the proposed resolution's consistency with the structure of creditor preference outside of bankruptcy. For a more general discussion of how the character of legal rules and the quality of law enforcement affect financial activity, see La Porta et al. (1996, 1997).

8. See Sherer (1998) for an article on the restructuring plan proposed for Alphatec Electronics PLC.

9. To address this situation, the Korean government proposed legislation, in early 1998, that would restrict the circumstances in which management could apply to the courts for protection. Under current Korean law, a company can file for liquidation, reorganization, or court mediation. It is estimated that almost all large company filings have been for court mediation. Korean commentators have asserted that filings for the court mediation option are often undertaken by managements seeking to retain authority rather than for the purpose of present liquidation. Under the proposed legislation, debtor companies would not be permitted to withdraw from a proceeding once an order has been issued. It is anticipated that this change would address the problem of management abuse of the process.

10. However, the agreement did not call for limiting the benefits to signatories. For example, applications to the Federal Reserve from banks from countries that adhere to the Accord are required to meet the Basle guidelines as administered by their home country supervisors. An applicant from a country not subscribing to the Basle Accord is required to provide information regarding the capital standard applied by the home country regulator, as well as information required to make data submitted comparable to the Basle framework. See Misback (1993).

11. The gist of the U.S. implementation of prompt corrective action is to limit the discretion available to regulators with respect to the actions they require bank owners to take in response to lowered capital ratios. In contrast, the Japanese implementation can be interpreted as providing a menu of options for supervisors.

12. In its use here, the term Accord should be broadly construed to refer to the public documents that have been issued by the Basle Committee.

13. For details on the EU Directive on Deposit Guarantees, see McKenzie and Khalidi (1994).

14. Portugal and Sweden employ risk-adjusted deposit insurance premiums. The only other foreign countries with risk-adjusted deposit insurance premiums are Argentina and Bulgaria. See Garcia (1997). 


\section{REFERENCES}

Bank for International Settlements. 1997. FinANCIAL STABILITY IN Emerging MARKet ECONOMIES. Report of the Working Party on Financial Stability in Emerging Market Economies.

Bank of Korea. 1997. MonTHLy STAtistics Bulletin, December.

Basle Committee on Banking Supervision. 1997. CORE PRINCIPLES OF EFFECTIVE BANKING SUPERVISION.

Diaz-Alejandro, C. 1983. "Goodbye Financial Repression, Hello Financial Crash." Journal of DeVelopment ECONOMICS 19: 1-24.

Garcia, Gillian. 1997. "Commonalities, Mistakes and Lessons: Deposit Insurance." Paper presented at the Federal Reserve Bank of Chicago/ World Bank Conference on Preventing Banking Crises.

Gibson, Michael. 1997. "Information Systems for Risk Management.” In The Measurement of Aggregate Market Risk. Basle: Bank for International Settlements.

John, Kose, Anthony Saunders, and Lemma W. Senbet. 1995. "A Theory of Bank Regulation and Management Compensation." New York University Salomon Center Working Paper S-95-1.

Kane, Edward. 1995. "Difficulties of Transferring Risk-Based Capital Requirements to Developing Countries." PACIFIC-BASIN FINANCE JOURNAL 3, nos. 2-3 (July).

Key, Sydney J. 1997. "Financial Services in the Uruguay Round and the WTO." Group of Thirty Occasional Paper no. 54.
Krugman, Paul. 1996. “Are Currency Crises Self-Fulfilling?” NBER MACROECONOMICS ANNUAL.

1998. "Bubble, Boom, Crash: Theoretical Notes on Asia's Crisis." Unpublished note, January.

La Porta, Rafael, Florencio Lopez-de-Silanes, Andrei Shleifer, and Robert W. Vishny. 1996. "Law and Finance." NBER Working Paper no. 5661.

1997. "Legal Determinants of External Finance." NBER Working Paper no. 5879.

Longhofer, Stanley D. 1997. "Absolute Priority Rule Violations, Credit Rationing and Efficiency." Federal Reserve Bank of Cleveland Working Paper no. 9710.

McKenzie, George, and Manzoor Khalidi. 1994. "The EU Directive on Deposit Insurance: A Critical Evaluation.” JOURNAL OF COMMON MARKET STUDIES 32, no. 2 (June).

Misback, Ann E. 1993. "The Foreign Bank Supervision Enhancement Act of 1991.” Federal Reserve Bulletin 79, no. 1 (January).

Sherer, Paul M. 1998. "Major Thai Restructuring Would Pay 5\% to Creditors.” Wall Street Journal, February 4, p. A19.

Tomasie, Roman, and Peter Little, eds. 1997. INSOLVENCY LAW AND Practice IN Asia. FT Law \& Tax Asia Pacific.

The views expressed in this article are those of the author and do not necessarily reflect the position of the Federal Reserve Bank of New York or the Federal Reserve System. The Federal Reserve Bank of New York provides no warranty, express or implied, as to the accuracy, timeliness, completeness, merchantability, or fitness for any particular purpose of any information contained in documents produced and provided by the Federal Reserve Bank of New York in any form or manner whatsoever. 